\title{
Handling sticky resin by stingless bees (Hymenoptera, Apidae)
}

\author{
Markus Gastauer ${ }^{1,2,4}$, Lucio A. O. Campos $^{3} \&$ Dieter Wittmann $^{1}$
}

\begin{abstract}
'Institut für Nutzpflanzenwissenschaften und Ressourcenschutz (INRES), Fachbereich Ökologie der Kulturlandschaft: Tierökologie, Melbweg 42, 53127 Bonn, Germany.

${ }^{2}$ Laboratório de Ecologia Vegetal, Departamento de Biologia Vegetal, Universidade Federal de Viçosa, 36570-000 Viçosa-MG, Brasil.

${ }^{3}$ Departamento de Biologia Geral, Universidade Federal de Viçosa, 36570-000 Viçosa-MG, Brasil.

${ }^{4}$ Corresponding author. markus.gastauer@ufv.br
\end{abstract}

\begin{abstract}
Handling sticky resin by stingless bees (Hymenoptera, Apidae). For their nest defense, stingless bees (Meliponini) collect plant resins which they stick on intruders like ants or cleptobiotic robber bees causing their immobilization. The aim of this article is to identify all parts of stingless bee workers contacting these sticky resins. Of special interest are those body parts with anti-adhesive properties to resin, where it can be removed without residues. For that, extensive behavioral observations during foraging flight, handling and application of the resin have been carried out. When handling the resin, all tarsi touch the resin while walking above it. For transportation from plants to the nest during foraging flight, the resin is packed to the corbicula via tarsi and basitarsi of front and middle legs. Once stuck to the resin or after the corbicula had been unloaded, the bee's legs have to be cleaned thoroughly. Only the tips of the mandibles, that form, cut and apply the sticky resin, seem to have at least temporarily resin-rejecting properties.
\end{abstract}

KEY WORDS. Adhesion; Meliponini; nest defense; surface properties.

RESUMO. Manipulação de resinas pegajosas pelas abelhas-sem-ferrão (Hymenoptera, Apidae). Para sua defesa, abelhas-semferrão (Meliponini) coletam resinas vegetais para colar nos invasores de seus ninhos como formigas ou abelhas cleptobióticas causando a imobilização deles. O objetivo desse artigo é identificar todas as partes das operárias das abelhas-sem-ferrão que tocam na resina. De interesse especial são aquelas partes do corpo que repelem as resinas. Para isso, extensas observações foram realizadas tanto durante a coleta, como no tratamento e na aplicação das resinas. Durante a manipulação da resina, todos os tarsos das operárias encostam-se à resina quando andam sobre sua superfície. Para transportar a resinas das plantas para os ninhos durante o vôo de coleta, a resina é transferida para a corbícula via tarsos e basitarsos das pernas anteriores e médias. Uma vez coladas na resina ou depois que a corbícula foi descarregada, as pernas das operárias são meticulosamente limpas. Utilizadas na manipulação, corte e aplicação da resina pegajosa, somente as pontas das mandíbulas parecem ter, pelo menos temporariamente, propriedades repelindo resina.

PALAVRAS-CHAVE. Adesão; defesa do ninho; Meliponini; propriedades da superfície.

Stingless bees (Hymenoptera, Meliponini) collect resin from different plants using them for construction and defense (Armbruster 1984; Marsaioli et al. 1999; Michener 1974; Roubik 1989). When mixed with wax to form brood cells and other parts of the nest, the disinfectant properties of the resin assist to protect the bee's hive in the humid and warm tropical rain forests (Lokvam \& Braddock 1999; Velikova et al. 2000).

By means of resin distributed around the nest entrance, non flying intruders are stopped before entering the nest (Michener 1974; Roubik 2006). Attacks of cleptobiotic robber bees like Lestrimelitta limao (Smith, 1863) are stopped by resin (Sakagami \& Laroca 1963; Sakagami et al. 1993). For aerial defense, the worker bees hover nearby the entrance of the nest (Wittmann 1985; Wittman et al. 1990; Roubik 2006), their corbicula sometimes "loaded" with resin (personal observation) intercepting potential intruders.

For active immobilization of intruders inside the nest, resin is collected and stored in deposits within the nests, where it stays viscous and sticky for a long time (Nogueira-Neto
1997). From these deposits the worker bees take small portions of resin and stick them on the intruder's body until legs, antennae and wings are tied up one at another (Blum et al. 1970; Nogueira-Neto 1997).

Only few studies are available about the bees' handling of resin or its derivates like propolis (Sakagami \& Camargo 1964). The aim of this paper is to determine those body parts of stingless bees which are involved in handling the resin during foraging, deposition, construction and defense. Motion sequences of resin-handling bees were analyzed to identify all those body parts which get in contact and release the sticky resin.

\section{MATERIAL AND METHODS}

During this study nest-defense and resin-handling of seven neotropical stingless bees have been analyzed (Table I). Workers of Plebeia emerina (Friese, 1900), Plebeia wittmanni (Moure \& Camargo, 1989) and Tetragonisca angustula (Latreille, 1811) were observed in- and outside their hives at 
the campus of the Pontifícia Universidade Católica do Rio Grande do Sul (PUC-RS) in Porto Alegre, Rio Grande do Sul, Brazil. Furthermore, workers of T. angustula, Plebeia droryana (Friese, 1900), Plebeia lucii (Moure, 2004), Trigona spinipes (Fabricius, 1793) and Frieseomelitta varia (Lepeletier, 1836) were observed treating and collecting resin at the campus of the Universidade Federal de Viçosa (UFV), Minas Gerais, Brazil.

Observed worker bees and visited plants were identified by Betina Blochtein (PUC Rio Grande do Sul, Brazil) or Lucio A. O. Campos (UFV). Vouchers have been incorporated in the collections of the Entomological Museum of the UFV (UFV-B).

Except of T. spinipes, the bees' colonies were transferred to artificial wooden hives with removable caps as proposed by Nogueira-Neto (1997), the dimensions depending on the size of the colony and varying between $10 \times 10 \times 8 \mathrm{~cm}$ and $20 \times 20 \times 15 \mathrm{~cm}$.

The motion sequences during resin collection, resin deposition and application have been recorded with a Canon EX2Hi, in combination with an objective CL 8-120 (120 $\mathrm{mm}$ ), or a digital camcorder GR-DV400 from JVC in combination with a $4 \mathrm{X}$ close-up lens.

To film the bees' behavior inside the nest, the wooden cover of the hive had been substituted by a glass panel. The interior of the nest was illuminated with cold light.

Overall, 17 hours of film documents have been analyzed picture by picture using Windows Movie Maker ${ }^{\mathrm{TM}}$ to describe the motion sequences of worker bees treating resin (Table I).

Data on duration of picking up resin and unloading the corbiculae were extracted from the films. Data on duration of foraging flight, number of picked-up portions of resin and duration of pick-up of one portion were measured during field observations with a digital time-clock.

\section{RESULTS}

Picking-up resin. Picking up resin is identically in all examined species, regardless whether it is taken at a plant, a deposit inside the nest or from a corbicula of another bee. Before picking-up resin, the bee taps it briefly with her antennae. After that she either turns away or starts pick-up.

The following pick-up behavior can be divided into three phases:

1) With the inner side of the tips of her spoon-like mandible the worker bee forms a ridge on the surface of the resin source. For that, the mandibles are opened. Mandible 1 is pressed into the resin volume while mandible 2 stays merely on its surface. When closing the mandibles, mandible 1 shovels with the help of an articulated movement of the head resin towards mandible 2, so that an elevation emerges (Figs. 1, 5 and 6).

Then, the bee opens her mandibles again and turns her head in direction of mandible 2 . Simultaneously, mandible 1 stays more or less in place securing the elevation. When the mandibles are closed again, mandible 2 is pressed into the
Table I. Compilation of behavior observed and amount of films recorded on handling of resin by worker bees from seven species. Bee's activities are classified as "Forage" (consisting of pick-up of resin with the mandibles and transferring this portion to the corbicula), "Pick-up" of resin inside the nest, "Deposition" (including transportation as well as observations of construction and defense), and "Unloading the corbicula".

\begin{tabular}{|c|c|c|c|}
\hline Species & Behavior & $\begin{array}{c}\text { Recorded } \\
\text { observations } \\
\text { (min) }\end{array}$ & $\begin{array}{l}\text { Not recorded } \\
\text { observations }\end{array}$ \\
\hline \multirow[t]{3}{*}{ Tetragonisca angustula } & Forage & 120 & \\
\hline & Pick-up & 150 & \\
\hline & Deposition & 90 & \\
\hline Trigona spinipes & Forage & 45 & \\
\hline \multirow[t]{4}{*}{ Plebeia lucii } & Forage & 90 & \\
\hline & Pick-up & 120 & \\
\hline & Deposition & 90 & $\mathrm{x}$ \\
\hline & Unloading the corbicula & 60 & \\
\hline \multirow[t]{3}{*}{ Plebeia emerina } & Forage & 30 & \\
\hline & Pick-up & 60 & \\
\hline & Deposition & 30 & \\
\hline \multirow[t]{3}{*}{ Frieseomelitta varia } & Forage & - & $\mathrm{x}$ \\
\hline & Deposition & - & $\mathrm{x}$ \\
\hline & Unloading the corbicula & - & $\mathrm{x}$ \\
\hline \multirow[t]{2}{*}{ Plebeia wittmanni } & Take-up & 30 & \\
\hline & Deposition & - & $\mathrm{x}$ \\
\hline \multirow[t]{2}{*}{ Plebeia droryana } & Take-up & 30 & \\
\hline & Deposition & 30 & \\
\hline
\end{tabular}

resin and shovels more resin towards mandible 1 in order to increase the elevation.

By stepping forward a bit and continuing the described movement, the worker bee forms a ridge from that elevation (Fig. 2). When opening the mandibles the resin rarely sticks to the inner side of the mandible.

2) For biting off the ridge form the resin source, the worker bee bends her head underneath the thorax (see white line in Fig. 3). Stepping backwards, more and more of the resin portion is disconnected. While biting off the resin from the deposit, the mandibles work like cutting wedges, with tips hitting each other, instead of scratching one over the other like a pair of scissors. Finally the bee gets up and removes the resin from its source (Fig. 4).

3) Using the ventral side of the front legs the resin portion is centered below the bee's head. Then the tips of the mandibles are cleaned as follows: The tip of one mandible scratches over the inner side of the other and the other way round, while the almost spherical portion of resin is fixed to the tip of the relevant cleaning mandible.

When rasping over the resin's surface or biting off the accumulated ridge, less than one third of the mandibles touches the sticky resin directly.

Although the tarsi of all six legs step and walk over the resin's surface during pick-up and deposition, they do not 

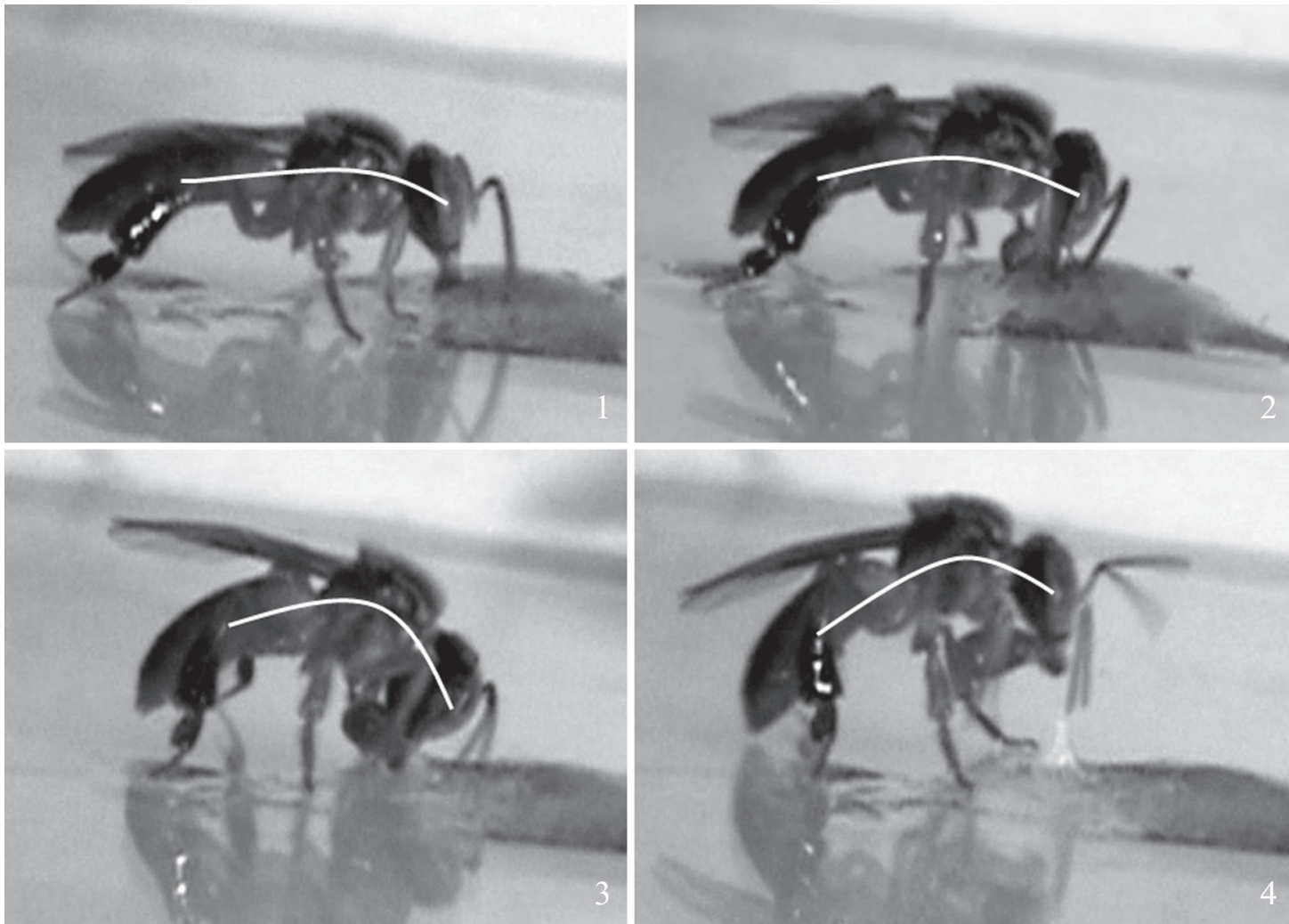

Fig. 1-4. Pick-up of a resin-portion from a deposit by Tetragonisca angustula. (1) With the tips of her mandibles, the bee forms a ridge on the surface of the resin source, $(2,3)$ to bite off the ridge form the resin source, the bee bents her head down and cuts the sticky resin with her mandibles, (4) finally she gets up and removes the resin from its source. The white lines show the body-posture of the bee during pick-up. In (3) the bee uses the tarsus of the right front leg to place the partly separated, slipping resin beneath her head, because it has got out of place.
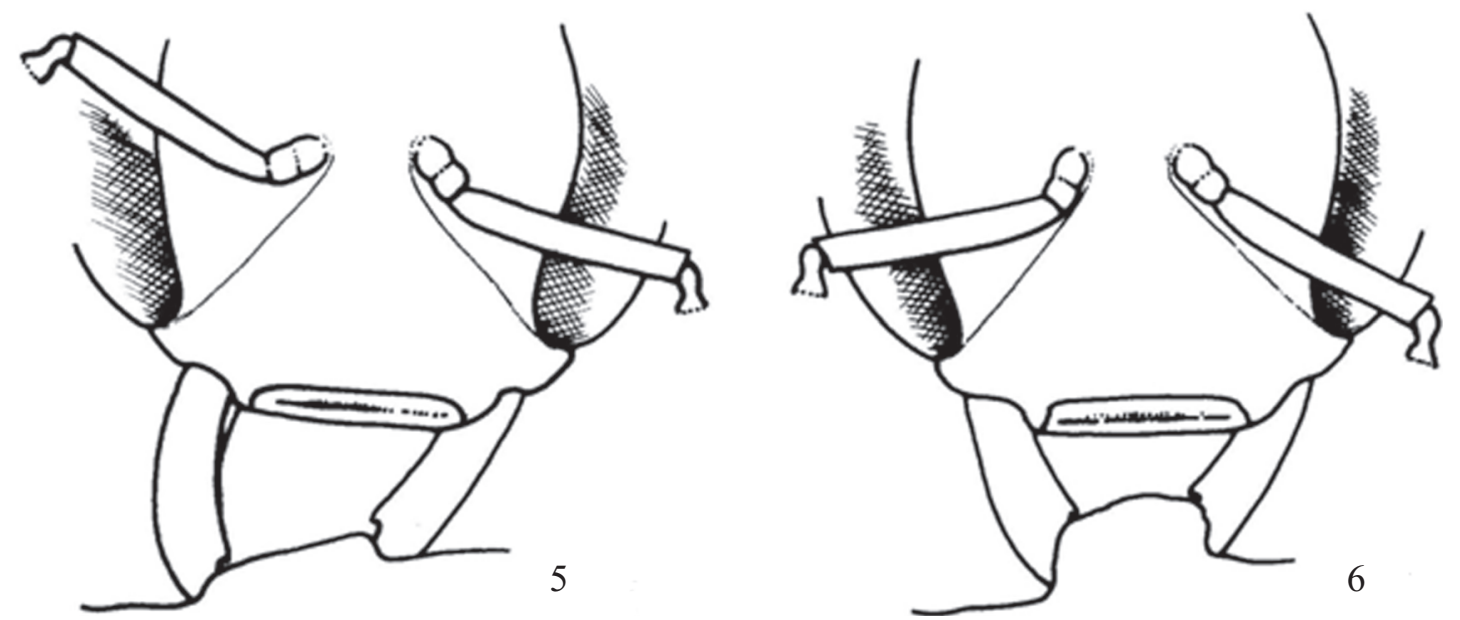

Fig. 5, 6. Position of the mandibles of Stingless Bees, here P. lucii, forming the ridge on the surface of the resin source. When closing her mandibles, the worker bee shovels resin with the right mandible (on the left side from the reader's view) towards the left mandible staying in place (Fig. 6). When opening the mandible again to enlarge the ridge, resin rarely sticks to the inner side of the left mandible (not shown).

stick to it at all. Only once T. angustula has been observed sticking with one tarsus to resin while walking on its surface. After she cleaned her tarsus thoroughly, she took off.

Workers of T. angustula picked up resin within $12 \mathrm{~s}$ to 2 $\min 6 \mathrm{~s}(\varnothing 45 \mathrm{~s}, \pm 30 \mathrm{~s}, \mathrm{n}=24)$, while workers of $P$. lucii took $22 \mathrm{~s}$ to $1 \mathrm{~min} 31 \mathrm{~s}(\varnothing 50 \mathrm{~s}, \pm 23 \mathrm{~s}, \mathrm{n}=24)$. The average size off the picked-up resin portion ranges between 0.5 to $1.6 \mathrm{~mm}$ in P. lucii (Ø $1.2 \mathrm{~mm} \pm 0.36 \mathrm{~mm}, \mathrm{n}=9)$ and 1.3 to $2.8 \mathrm{~mm}$ in $T$. angustula (Ø $2.2 \mathrm{~mm} \pm 0.51 \mathrm{~mm}, \mathrm{n}=7)$.

Loading the corbicula. In Figure $7-10$ we show how a T. angustula worker is loading her left corbicula with resin on a female Clusia fluminensis Planch. \& Triana flower. Hav- 
ing been picked-up the portion of resin is fixed at the ventral side of the praetarsus of the left front leg (Fig. 7).

The left middle leg passes over the front leg in order to transfer the resin to its basitarsus (Fig. 8). Finally the basitarsus sticks the resin above the already existing load of the left corbicula (Fig. 9). Immediately, the bee begins to take up the next portion of resin (Fig. 10). Details about duration of foraging flight, duration of loading up resin and number of portions loaded are presented in Table II.
Unloading the corbicula. The unloading of the corbicula has been observed in P. lucii and F. varia.

Returning from the foraging flight, the foraging P. lucii chooses where to deposit the collected resin. In the case shown in Fig. 4, the resin is deposited on a honey pot. With the bottom side of the tarsi of the middle leg, the bee starts to brush the resin top-down from both corbiculae (Fig. 12). The bee steps forward when the resin is dropping onto the destination to liberate the tarsi of the hind legs being polluted by
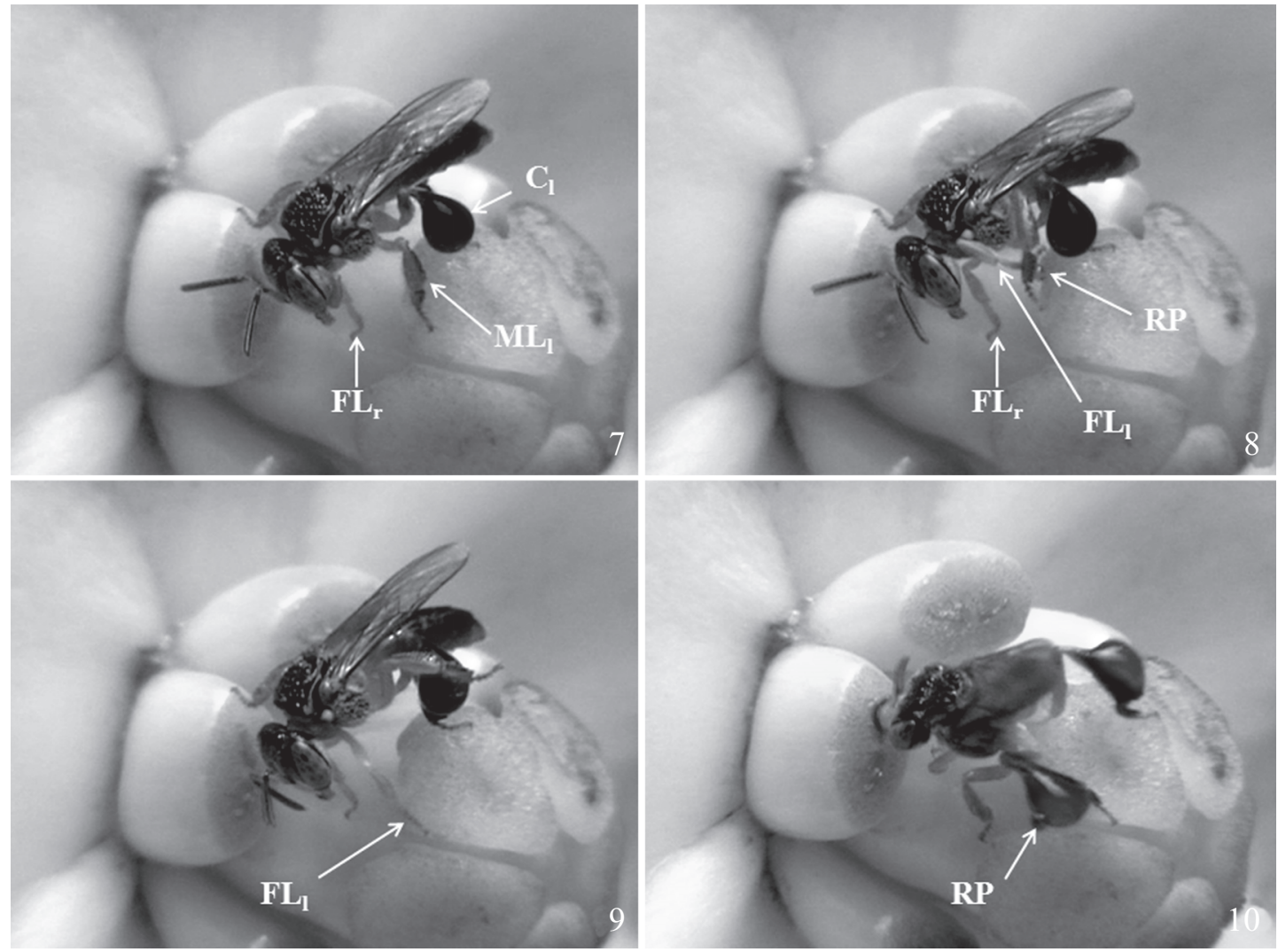

Fig. 7-10. Tetragonisca angustula collecting resin from a female flower of Clusia fluminensis. (7) The picked-up portion of resin is transferred to the praetarsus of the left front leg ( $\left.\mathrm{FL}_{1}\right)$, here hidden behind torax and beneath head ( $\mathrm{FL}_{\mathrm{r}}$ : right front leg, $\mathrm{ML}_{1}$ : left middle leg, $\mathrm{C}_{1}$ : left corbicula), (8) resin (RP) is transferred to the basitarsus of the middle leg, (9) which sticks the resin to the corbicula. (10) Afterwards the worker bee starts to pick up the next portion of resin.

Table II. Duration of resin-foraging flight (ttot, in seconds) of worker bees from Tetragonisca angustula, Trigona spinipes, Plebeia lucii and Plebeia emerina on Euphorbia milii Des Moul., Clusia fluminensis Planch. \& Triana and Eucalyptus sp. Npor=average number of resin-portions picked up during foraging flight, tpor = average duration (in seconds) to picking-up and loading one portion of resin in the corbicula, $\mathrm{N}=$ number of observations. All data with standard deviation, minimum and maximum values.

\begin{tabular}{|c|c|c|c|c|c|c|c|}
\hline \multirow{2}{*}{$\frac{\text { Bee species }}{\text { Plant species }}$} & \multicolumn{2}{|c|}{ T. angustula } & \multicolumn{2}{|c|}{ T. spinipes } & \multirow{2}{*}{$\frac{\text { P. lucii }}{\text { C. fluminensis }}$} & \multirow{2}{*}{$\frac{\text { P. emerina }}{\text { E. milii }}$} & \multirow{2}{*}{ Total } \\
\hline & E. milli & C. fluminensis & C. fluminensis & Eucalyptus sp. & & & \\
\hline \multirow[t]{2}{*}{ Ttot $[\mathrm{s}]$} & $353( \pm 161)$ & $228( \pm 125)$ & $250( \pm 81)$ & $322( \pm 79)$ & $329,1( \pm 70)$ & $204,8( \pm 76)$ & $277,3( \pm 101)$ \\
\hline & $227-623$ & $129-398$ & $147-376$ & $269-438$ & $216-412$ & $117-317$ & $129-623$ \\
\hline \multirow[t]{2}{*}{ Npor } & $10.8( \pm 4,2)$ & $9.75( \pm 3,4)$ & $8.4( \pm 1,6)$ & $10.5( \pm 1,3)$ & $8.5( \pm 1,6)$ & $7.2( \pm 1,5)$ & $9.1( \pm 2,5)$ \\
\hline & $8-18$ & $5-14$ & $6-11$ & $9-12$ & $6-11$ & $5-9$ & $5-18$ \\
\hline \multirow[t]{2}{*}{ Tpor [s] } & $32.0( \pm 4,0)$ & $25.0( \pm 11,4)$ & $30.6( \pm 10,7)$ & $31.5( \pm 11,5)$ & $38.7( \pm 4,7)$ & $28.0( \pm 6,6)$ & $31.1( \pm 9,5)$ \\
\hline & $28-37$ & $16-36$ & $16-41$ & $25-49$ & $35-45$ & $19-35$ & $16-49$ \\
\hline $\mathrm{N}$ & 5 & 8 & 8 & 4 & 8 & 5 & 38 \\
\hline
\end{tabular}



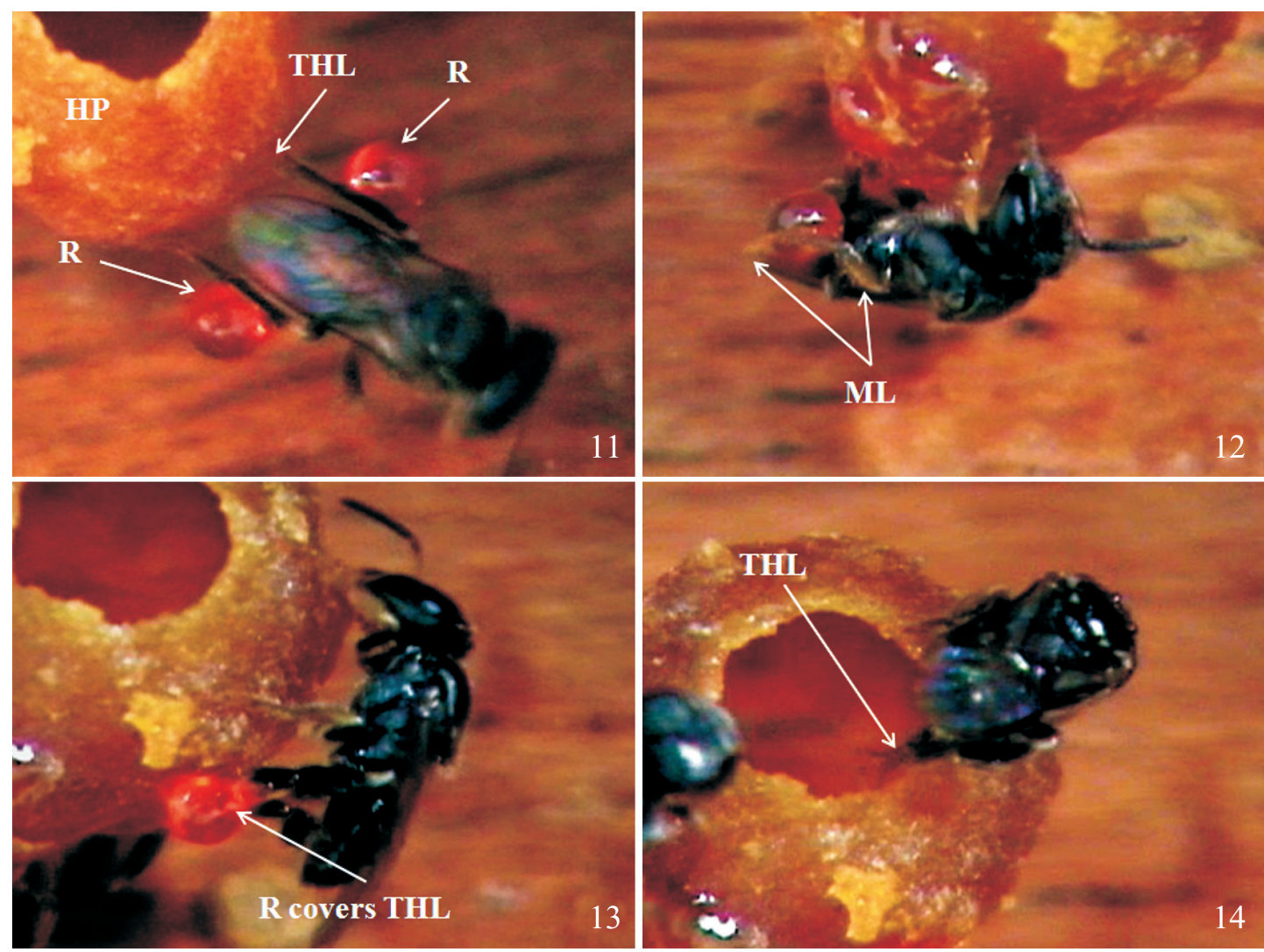

Fig. 11-14. Plebeia lucii unloads the corbicula. HP: honey pot, THL: tarsus of the hind leg, R: resin, ML: middle leg.

the gluey resin (Fig. 13). The contaminated tarsi of the middle and the hind legs are cleaned: The inner and the bottom side of the tarsi of the hind legs (Fig. 14) alternating with the inner and the bottom side of the middle leg tarsi are rubbed one at another. Residues of resin are wiped off near the recently deposited resin.

Unloading the resin completely from the two corbiculae took 7 to $13 \min (\varnothing 544 \mathrm{~s}, \pm 128 \mathrm{~s}, \mathrm{n}=5)$. Nearly $75 \%$ of this time was spent on cleaning the tarsi.

Figure 15 shows a F. varia worker unloading the corbicula of a resin-carrying nest mate. In front of the entrance, the unloading bee positions herself at the side of the foraging one and begins to pick up a portion of resin with her mandibles. Afterwards, the foraging bee cleans extensively her corbiculae by brushing residues of resin top-down with the tarsi of the middle legs. By that, she contaminates the tarsi of the hind and the middle leg with resin which are cleaned afterwards as described for $P$. lucii above.

Transportation and deposition of resin within the nest. When transported inside the nests, i.e. between the deposit and a construction site or an intruder, resin is hold by both tips of the mandibles, being fixed beneath the bee's head (Fig. 16).

To remove resin from her mandibles, the bee attaches the resin at its destination (Fig. 17) and opens her mandibles (Fig. 18). In comparison with the corbiculae, the resin is easily removed from the tips of the mandibles, without leaving residues behind.

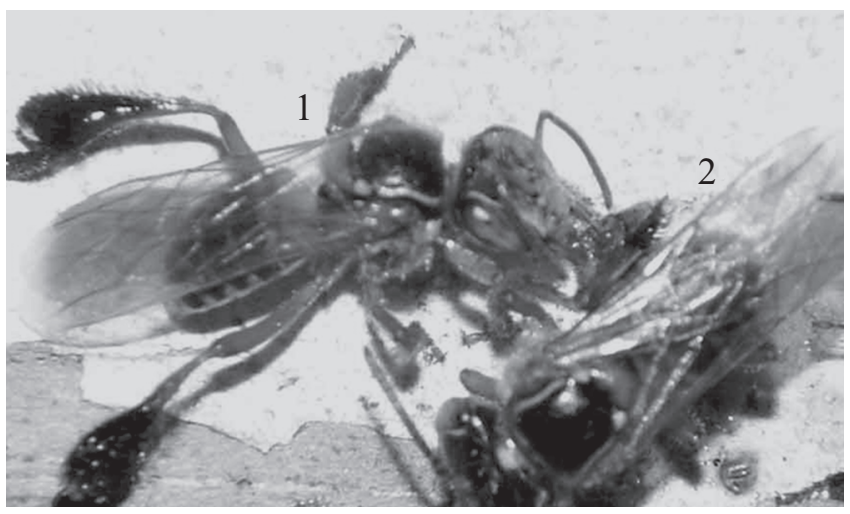

Fig. 15. Unloading the corbicula by Frieseomelitta varia. Bee 1 picks up the resin from the corbicula of the foraging bee 2 .

\section{DISCUSSION}

Meyer (1956) asserted the same motion sequence when worker bees of Apis mellifera (Linnaeus, 1758) take up a portion of propolis. She also observed $A$. mellifera tap the surface of the resin with the antenna before beginning the pick-up. The stimuli necessary to start pick-up at a plant or inside a nest are still unknown.

Sakagami \& Camargo (1964) observed the resin foraging flight and the loading of the corbicula with cerumen in a similar way as we described it above. Additionally, they ob- 

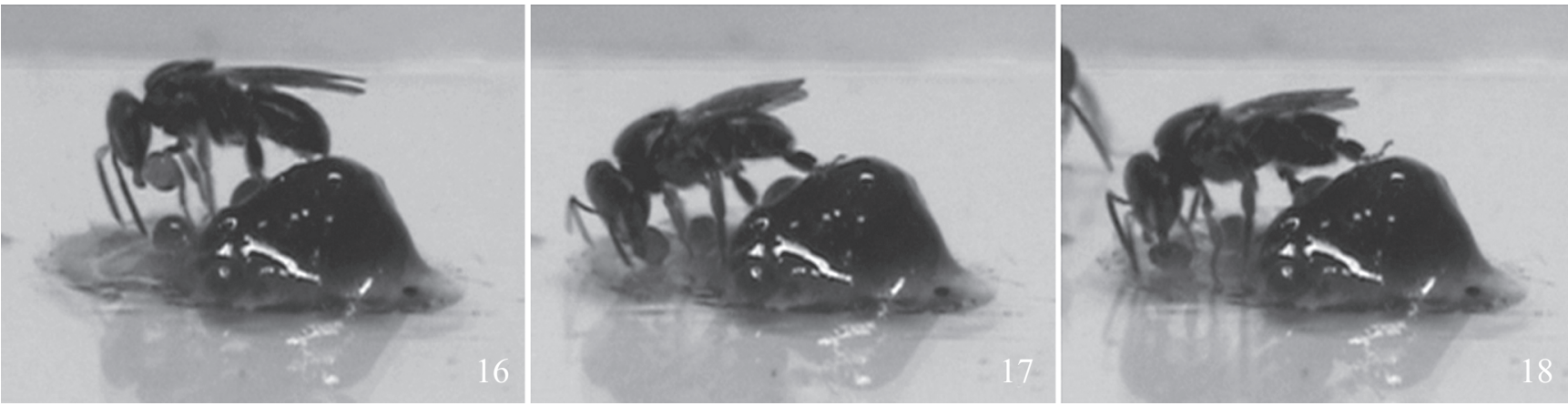

Fig. 16-18. Transportation and deposition of resin by Plebeia emerina.

served Scaptotrigona postica (Latreille, 1807) raising their hind legs loaded with cerumen either to estimate the absolute weight of the load or to test the balance between both sides. This behavior is lacking in species we observed.

Duration of pick-up, size of picked-up resin portion as well as number of picked-up portions per foraging flight vary extremely. In our study has not been evaluated, if duration depends on the amount of resin picked up, or if the other parameters are correlated with the age of the worker bee, or viscosity, stickiness, or age of the resin. Attacks on the bees' hive by ants or L. limao might also influence size and duration of the picked-up resin portion.

Roubik (1989) observed that worker bees of T. spinipes use the middle legs to withdraw the resin from the corbicula as related for $P$. lucii, while Meyer (1956) reports how a worker bee of $A$. mellifera unloads the resin from a corbicula of a collecting bee as described for $F$. varia above. Similar behavior has been observed by Sakagami \& Camargo (1964) on cerumen-collecting and -thieving in S. postica. Because the unloading of the corbicula has been observed very rarely the question remains if each species uses only one method or if the two techniques occur side by side in the same colony.

Chemical analysis of resin deposited by Stingless Bees revealed that it is mixed with cuticular hydrocarbons and wax of the bees (Patricio et al. 2002). In our research worker bees have not been observed to mix wax or other substances with the collected resin. Further examinations are necessary to explain how these substances are added to the resin. Of special interest is the influence of these additives to the durability of the resin: Are the bees able to prevent resin from its natural process of going dry and losing its characteristic stickiness by adding wax or other substances as proposed by Santos et al. (2009).

Our observations show that beside the corbicula, the tarsi of all legs and the inner side of the mandibles' tips touch the resin while treating it. Neither the corbiculae nor the tarsi show anti-adhesive properties to resin; after being contaminated, they were cleaned thoroughly. Roubik (1989) observed stingless bee workers with hardened resin on their hindlegs at all times, implying that it can no longer be removed. A small contact area might prevent the tarsi from sticking to the gluey resin when walking on its surface.
Stingless Bees use the ventral, inner side of the tip of the spoon-like mandible to form and cut the resin during pickup. The contact area between mandible and resin is small, covering less than one third of the mandible, but this does not explain, why worker bees can remove the resin that easily and without any residues and why resin sticking to the mandible's inner side has been observed only few times during our investigations.

Obviously the surface of the mandible's tip has temporarily resin-rejecting properties. As the surface properties are the product of anatomical structure and chemical composition (Betz \& Kölsch 2004), further researches should analyze the micro-structure of the cuticle of the bee's mandible and compare it with other insect cuticles that do not reject resin. Furthermore, the adhesive properties of the bees' cuticle should be described using atomic force microscopy (Döring 2001) or cryo-scanning electron microscopy (Voigt \& Gorb 2008).

\section{REFERENCES}

Armbruster, W. S. 1984. The role of resin in angiosperm pollination: ecological and chemical considerations. American Journal of Botany 71: 1149-1160.

Betz, O. \& G. Kölsch. 2004. The role of adhesion in prey capture and predator defence in arthropods. Arthropod Structure \& Development 33: $3-30$.

Blum, M. S.; R. M. Crewe; W. E. Kerr; L. E. Keith; A. W. Garrison \& M. M. Walker. 1970. Citral in stingless bees: isolation and functions in trail-laying and robbing. Journal of Insect Physiology 16: 1637-1648.

Döring, A. 2001. Rasterkraftmikroskopische Untersuchungen an Haftklebstoffen. PhD-thesis, Universität Ulm, 125 p.

Lokvam, L. \& J. F. Braddock. 1999. Anti-bacterial function in the sexually dimorphic pollinator rewards of Clusia grandiflora (Clusiaceae). Oecologia 111: 534-540.

Marsaioli, A. J.; A. L. M. Porto; R. A. C. Gonçalves; C. M. A. Oliveira; G. P. Manfio \& V. Bittrich. 1999. The ecosystem of microorganisms, bees, and Clusia floral resin and oils, from the chemistry point of view. IUPAC, $8 \mathrm{p}$.

Meyer, W. 1956. Propolis bees and their activities. Bee World 37: 25-36.

Michener, C. 1974. The social behavior of bees: A comparative study. Cambridge, Harvard University Press, 404 p.

Nogueira-Neto, P. 1997. Vida e criação de abelhas indígenas sem ferrão. São Paulo, Editora Tecnapis, 445 p.

Patricio, E. F. L. R. A.; L. Cruz-Lópes; R. Maile; J. Tentschert; G. R. Jones \& E. D. Morgan. 2002. The propolis of stingless bees: terpenes from the tibia of three Frieseomelitta species. Journal of Insect Physiology 48: $249-254$. 
Roubik, D. W. 1989. Ecology and natural history of tropical bees. Cambridge University Press, $514 \mathrm{p}$.

Roubik, D. W. 2006. Stingless bee nesting biology. Apidologie 37: 124 143.

Sakagami, S. F. \& J. F. M. Camargo. 1964. Cerumen collection accompanied by thieving and attacking in a stingless bee, Nannotrigona (Scaptotrigona) postica (Latreille), with a consideration on territoriality in social insects. Revista de Biología Tropical 12: 197-207.

Sakagami, S. F. \& S. Laroca. 1963. Additional observations on the habits of the cleptobiotic stingless bees, the Genus Lestrimelitta Friese (Hymenoptera, Apoidea). Journal of the Faculty of Science. Hokkaido University 15: 319-339.

Sakagami, S. F.; D.W. Roubik \& R. Zucchi. 1993. Ethology of the robber stingless bee, Lestrimelitta limao (Hymenoptera, Apidae). Sociobiology 21: $237-277$.

Santos, C. G.; F. L. Megiolaro; J. E. Serrão \& B. Blochtein. 2009. Morphology of the head salivary and intramandibular glands of the stingless bee Plebeia emerina (Hymenoptera: Meliponini) workers associated with propolis. Annals of the Entomological Society of America 102: 137-143.

Velikova, M.; V. Bankova; I. Tsvetkova; A. Kujumgiev \& M. C. Marcucci. 2000. Antibacterial ent-kaurene from Brazilian propolis of native stingless bees. Fitoterapia 71: 693-696.

Voigt, D. \& S. Gorb. 2008. An insect trap as habitat: cohesion-failure mechanism prevents adhesion of Pameridea roridulae bugs to the sticky surface of the plant Roridula gorgonias. Journal of Experimental Biology 211: 2647-2657.

Wittmann, D. 1985. Aerial defence of the nest by workers of the stingless bee Trigona (Tetragonisca) angustula Latreille (Hymenoptera: Apidae). Behavior Ecology and Sociobiology 16: 111-114.

Wittmann, D.; R. Radtke; J. Zeil; G. Lübke \& W. Francke. 1990. Robber bees (Lestrimelitta limao) and their host chemical and visual Cues in nest defense by Trigona (Tetragonisca) angustula (Apidae: Meliponinae). Journal of Chemical Ecology 16: 631-641.

Received 23/3/2010; accepted 14/3/2011

Editor: Maria Cristina Gaglianone 